\title{
A Review of Multilevel Inverter Based Active Power Filter
}

\author{
Madhukar Waware and Pramod Agarwal
}

\begin{abstract}
Use of nonlinear loads at high voltages has increased tremendously in industry. These non-linear loads distort power quality by generating harmonics. Conventional active filters have limitations in high power high voltage systems. Use of multilevel inverter in active filters effectively reduces harmonics in high voltage systems eliminating need of high cost and bulky transformer. This paper presents the state of art of different topologies of multilevel inverter (MLI) used for active power filters (APF), the different control techniques and advanced modulation methods. It is aimed to provide a broad perspective on the status of MLI based APF technology to researchers and application engineers dealing with power quality issues in high voltage systems.
\end{abstract}

Index Terms-Multilevel Inverter, Active Power Filters reference generation, modulation techniques.

\section{INTRODUCTION}

The Electrical power generated and distributed to the loads by electrical power system is considered to be of excellent quality when voltage and current wave shapes are pure sinusoidal of fixed frequency. Any significant deviation in the magnitude of voltage, current and frequency or their waveform purity may result in a power quality problem.

In recent years power electronic converters are widely used in industrial as well as domestic applications for the control of power flow for automation and energy efficiency. Commercial facilities such as office complex, departmental stores, hospitals, data centers etc. use high efficiency fluorescent lighting with electronic ballasts which employ switch mode power supply, single phase SMPS, battery chargers, rectifiers, inverters, three phase power converter fed drives, arc furnaces, arc welding, discharge lighting and saturable reactors are the examples of non-linear loads .

All these loads draw the non sinusoidal currents resulting in current harmonics

Harmonic currents produced by non-linear loads are injected back into the supply systems. These currents can interact adversely with power system equipments such as capacitors, transformers, motors, energy and demand metering causing additional losses, overheating and overloading. These harmonic currents can cause interference with telecommunication lines and also affect

Manuscript received July12, 2010

Madhukar Waware ,Member, IACSIT,IEEE,Pramod Agarwal, Member, IEEE

Madhukar Waware is pursuing Ph.D. program in Electrical Engineering Department , Indian Institute of Technology Roorkee-247667, India(emailmwaware@ rediffmail.com ).

Pramod Agarwal is a professor in Electrical engineering Department, Indian Institute of Technology Roorkee-247667, India(emailpramgfee@iitr.ernet.in). the normal working of computers, telephone systems, controllers, sophisticated electronic equipments.

There are number of devices available to control harmonic distortion. Passive filters are used for harmonic mitigation due to their advantages of simplicity, low cost and easy maintenance. But, disadvantages that these filters introduce are numerous as; the filter can be overloaded, parallel resonance with network impedance, de-tuning of harmonic frequency with aging of passive components, high current rating of series filter, and the filtering characteristics are dependent on the source impedance which is not exactly known.

Generally active power filters are seen as a viable alternative over the classical passive filters to compensate harmonics and reactive power requirement of nonlinear loads [1][2]. It acts as a harmonic current source which injects an anti-phase but equal magnitude of the harmonic and reactive load current. As a result components of harmonic currents contained in the load current are cancelled and the source current remains sinusoidal and in phase with the respective phase to neutral voltage. Fig.1a shows the basic principle of a shunt active filter, which is controlled into a closed loop manner to actively shape the source current into sinusoid. In Fig.1b the current and voltage waveforms are shown in case of shunt active power filter (SAPF). The load is assumed a three phase diode rectifier with an inductive load. The SAF injects the compensating current Ic into the line to cancel the harmonics contained in the load current. The active filters are also called as active power line conditioner as these are able to compensate current and voltage harmonics, reactive power,

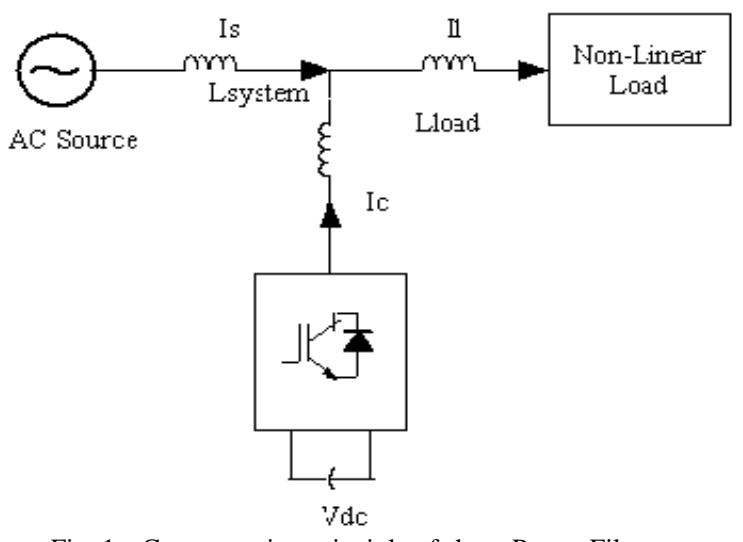

Fig. 1.a Compensation principle of shunt Power Filter

regulate terminal voltage, suppress flicker and to improve voltage balance in three phase systems. The advantage of active filtering is that it automatically adapts to changes in the network characteristics, eliminating the risk of resonance between the filter and network impedance. 


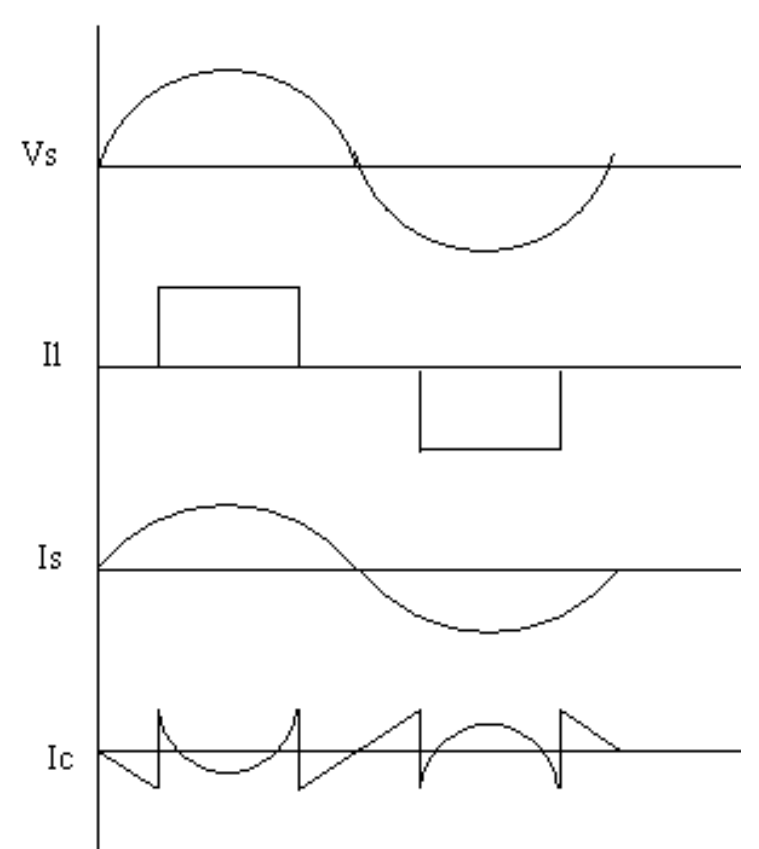

Fig. 1.b Theoretical waveforms for SAPF

Many technical papers related with active power filter have been presented during last two decade, most of them dealt with their principles of operation, design of control schemes and presentation of different techniques to calculate the reference signals required by the control scheme and do not address the limitations in medium and high voltage application. Nowadays many controlled processes in industry are being carried out at high voltage levels and high voltage drives are being extensively used; application of active power filter in high voltage system has become an important and interesting issue. But the current active filters have limitations in medium and high voltage applications due to semiconductor reverse voltage rating constraint, the necessity of switching high voltage and high current causes high power loss, high level of a dv/dt associated to the communication system, generating EMI as well as insulation degradation in electronic and electrical systems [3].

Active power filter can be used in high voltage system by two ways. In one way series connected semiconductor switches can be used but this configuration faces problems of unbalanced static and dynamic voltage sharing due to spread of device characteristic and mismatch of drive circuit. It further requires large number of snubber components which causes additional losses and affect reliability. The second way is use of step up transformer with active power filter. In Fig. 2 one method to use APF with transformer in high voltage system is shown, in which two secondary windings transformer is used [4]. One secondary is used for non linear load and second is used to feed filter current to make source side current, harmonic free. But this scheme requires two secondary windings transformer.

Fig.3 shows another configuration to use two level inverter APF in high voltage system. In this, the VA rating of transformer required is much higher than the rms VA rating of system due to harmonic reactive power. The use of transformer also causes difficulties in control due to DC magnetizing and surge overvoltage problems resulting from saturation of the transformers in transient states. Similarly there will be high magnitude of current on low voltage side and cause more losses. High rating transformers also occupy a large area i.e. about $40 \%$ of the total system space. Thus the use of transformer results in costly and bulky system.

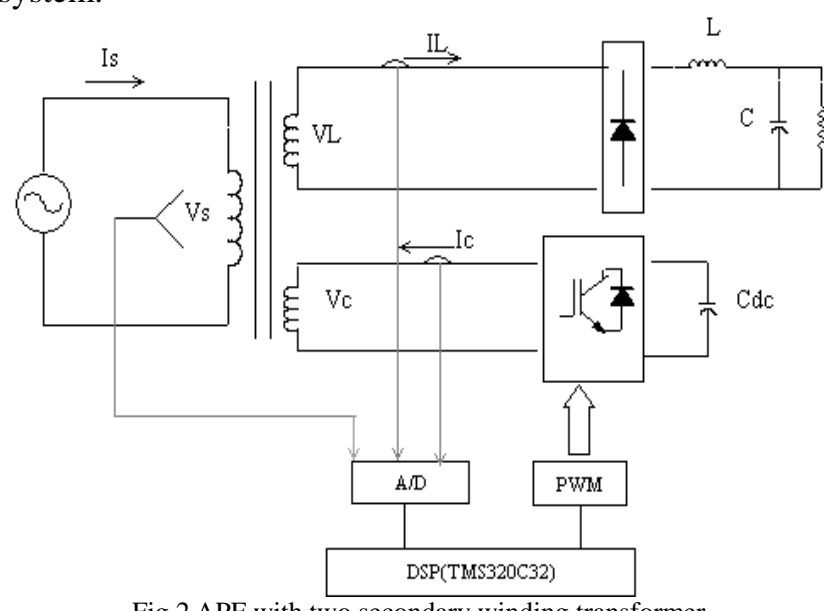

Fig.2 APF with two secondary winding transformer for high voltage system.

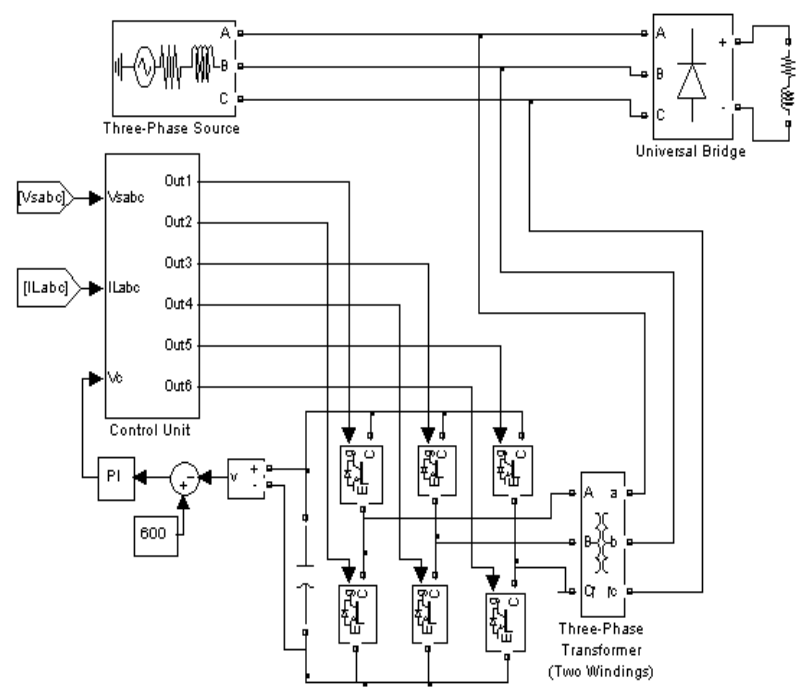

Fig.3. Two level inverter based APF with Conventional Transformer

High voltage inverters development based on multilevel inverter has attracted the attention of power electronics community, especially for motor drive applications and reactive power compensation. Multilevel PWM inverters can be connected to high voltage sources without coupling transformer.

\section{TOPOLOGIES OF MULTILEVEL INVERTYERS}

The multilevel inviter circuits have been around for more than 30 years. In 1975[5], the cascade inverter was first defined with a format that connects separately dc source full bridge cells in series to synthesize a stair case ac output voltage. Although cascade inverter was invented earlier, its application didn't prevail until the mid 1990s. Two major patents [6][7] were filed to introduce the superiority of cascade inverter for motor drive and utility applications.

Multilevel inverters include an array of power semiconductors and capacitors. The commutation of the switches permits the summation of capacitor voltages, 
which reach high voltages at the output, while the power semiconductors must withstand only reduced voltages. Following are different multilevel inverter topologies [8][12]
A) Diode clamped
B) F lying capacitor
C) Cascade H-bridge

\section{A. Diode clamped multilevel inverter.}

An $m$ level diode clamp converter typically consists of (m-1) capacitors on the dc bus and produces $m$ levels of the phase voltage [13]-[17]. Fig.4 Shows a single phase three level diode-clamped inverter. The capacitors $\mathrm{C} 1$ and $\mathrm{C} 2$ are used to split the dc-bus voltage into three levels with middle point $n$ as the neutral point.

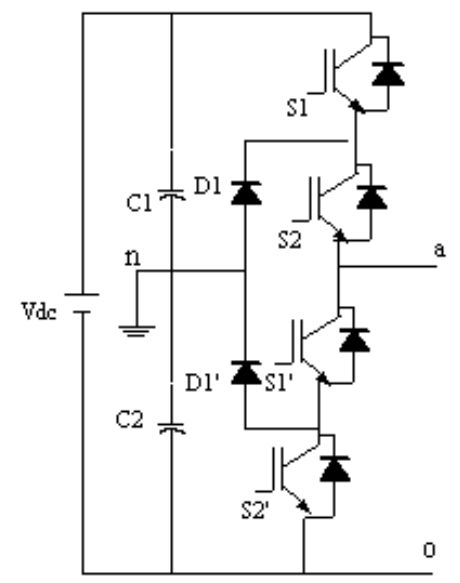

Fig. 4. Three Level Diode Clamped Inverter

The output voltage van has three states: Vdc/2, 0 and $\mathrm{Vdc} / 2$. For voltage level $\mathrm{Vdc} / 2$, switches $\mathrm{S} 1$ and $\mathrm{S} 2$ to be turned on; for $-\mathrm{Vdc} / 2$ switches $\mathrm{S} 1$ ' and $\mathrm{S} 2$ ' should be turn on and for 0 level S2 and S1' need to be turned on . Diodes D1 and D1' clamp the switch voltages to half the level of the dc-bus voltage. When both S1 and S2 turn on, the voltage across a and 0 is $\mathrm{Vdc}$. In this case, D1' balances out the voltage sharing between $\mathrm{S} 1$ ' and $\mathrm{S} 2$ ' with $\mathrm{S} 1$ ' blocking the voltage across $\mathrm{C} 1$ and $\mathrm{S} 2$ ' blocking the voltage across $\mathrm{C} 2$.

Fig.5. shows the active power filter based on three levels neutral point clamped (NPC) voltage source inverter [18]. The three level NPC inverter output voltage must be able to generate an output current that follows the respective reference current which contain harmonic and reactive component required by the load [19]-[21].

In case of diode clamped inverter as the number of levels increases the circuit configuration becomes more complicated. Although each active switching device is only required to block a voltage level of $\mathrm{Vdc} /(\mathrm{m}-1)$, the clamping diodes need to have different voltage rating for reverse voltage blocking. If the blocking voltage rating of each diode is same as the active device rating, number of diodes required for each phase will be $(m-1) *(m-2)$. When $\mathrm{m}$ is very high, number of diodes required will make the system impractical to implement. The conduction periods of $\mathrm{S} 1$ and S2 are also different and such an unequal conduction duty requires different current rating for switching devices.

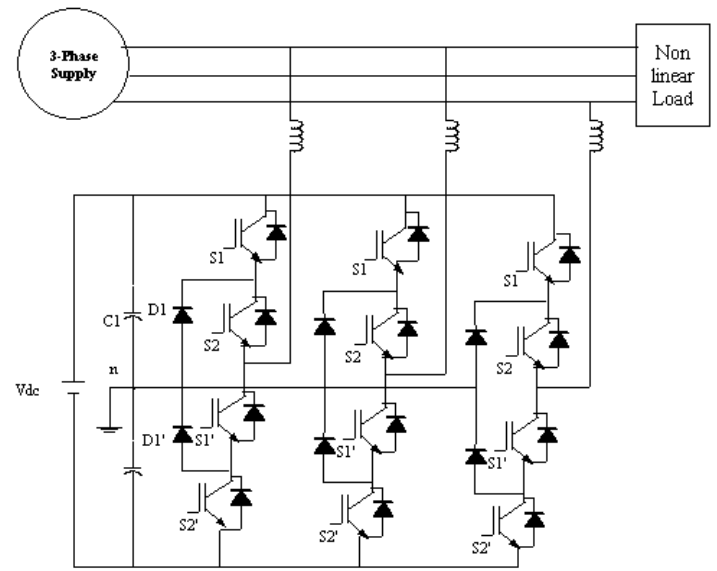

Fig. 5 Active power filter Based on three levels NPC Inverter

\section{B. Flying capacitor multilevel inverter}

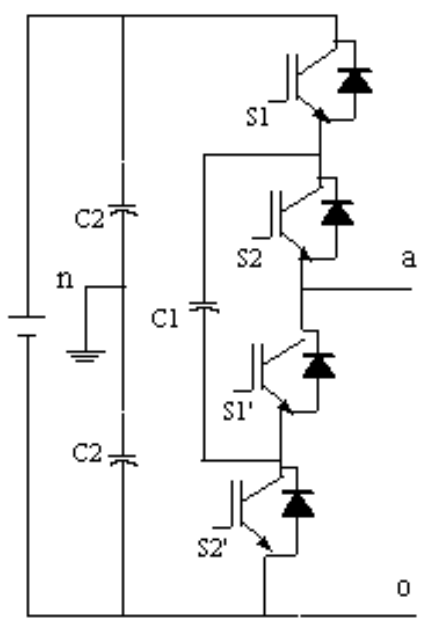

Fig.6 Three-Level Capacitor Clamped multilevel Inverter

In flying capacitor multilevel inverter (FCMLI) output voltage synthesis is performed by turning on switches so that addition or subtraction of the capacitor voltages takes place [22]-[24]. Three level flying capacitor inverter is shown in Fig.6, in which the independent capacitor clamps the device voltage to one capacitor voltage level. Output across $\mathrm{a}$ and $\mathrm{n}$ has three voltage levels i.e. $\mathrm{Van}=\mathrm{Vdc} / 2,0$ or $-\mathrm{Vdc} / 2$. For voltage level $\mathrm{Vdc} / 2$, switches $\mathrm{S} 1$ and S2 need to be turn on and for the $-\mathrm{Vdc} / 2$ voltage switches $\mathrm{S} 1$ ' and $\mathrm{S} 2$ ' should be turn on and for the 0 level either pair (S1 S1') or (S2 S2') needs to be turn on. Clamping capacitor $\mathrm{C} 1$ is charged when $\mathrm{S} 1$ and $\mathrm{S}^{\prime}$ ' are turned on, and discharged when S2 and S2' are turned on. The charge of $\mathrm{C} 1$ can be balanced by proper selection of the 0-level switch combination. The major problem in this inverter is the requirement of large number of storage capacitors. If the voltage rating of each capacitor is same as that of the main power switch then an $\mathrm{m}$ - level converter will require a total of $(\mathrm{m}-1) *(\mathrm{~m}-2) / 2$ auxiliary capacitors per phase in addition to (m-1) main dc bus capacitors. When number of levels increase, the system will be more difficult to package and more expensive. The inverter control will be very complicated.

\section{Cascade multilevel inverter}

Cascade multilevel inverters are increasingly regarded in high power applications due to its direct high voltage output 
with no need of transformer. Its other advantages are also discussed in [25][26]. An m-level cascade multilevel inverter consists of (m-1)/2 single-phase full bridges in which each bridge has its own separate dc source. This inverter can generate almost sinusoidal waveform voltage with only one time switching per cycle as the number of levels increase. It can solve the size-and-weight problems of conventional transformer-based multipulse inverters and the component- counts problems of multilevel diode clamped and flying-capacitor inverters.

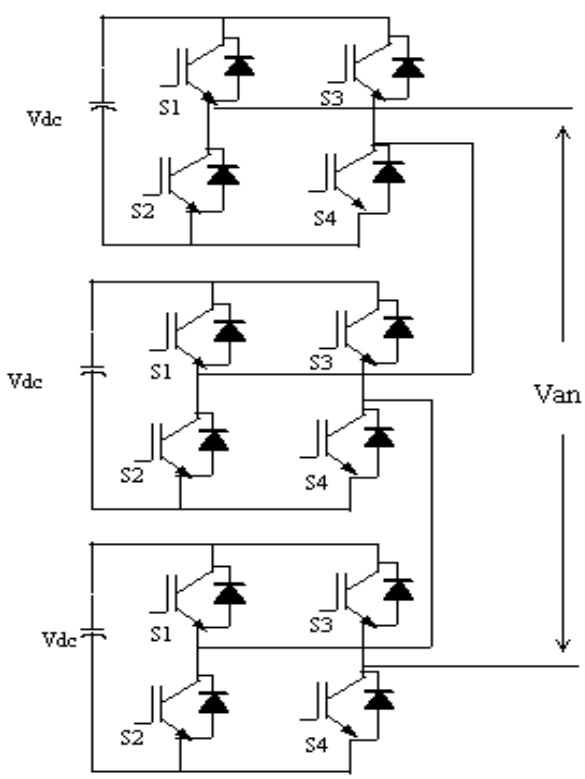

Fig.7 a Cascade H-Bridge multilevel inverter

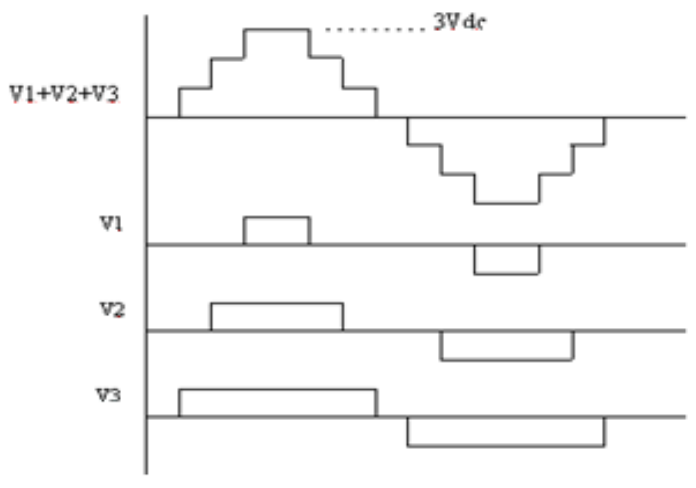

Fig. 7.b. Output waveform.

In Fig.7. (a) cascade multilevel inverter is shown. It consists of three single phase full bridges connected in series in this configuration [27]-[30]. If $S$ is equal to number of full bridge cells then the number of output levels is $2 \mathrm{~S}+1$. with $S=3$ there will be seven levels in phase voltage and peak magnitude is SVdc .. For active power filter application there is no need of active power output from the inverter. So separate dc source for each converter bridge is not required. The APF will draw small power from source to compensate the switching losses and capacitor losses.

Cascade inverters are again modified to reduce number of devices for the same level of output known as hybrid asymmetric multilevel topologies as in [31][32]. In the hybrid topologies each dc source drives a different voltage level, due to these characteristics, they are named asymmetric. The hybrid concept is related to power switching devices that are used in each inverter. Each inverter cell operates at different voltage and switching frequency. The converter with higher dc voltage operates at lower switching frequency and GTO can be used as switching device while the converter with lower voltages can operate at higher switching frequency and for that IGBT is a suitable device. Defining $S$ as the cell number and $n=1$, $2, \ldots \mathrm{S}$, the hybrid topologies are classified as follows [33][34].

\section{1) Hybrid Multilevel Inverter With $2 s-n$ vdc Factor}

Fig.8. shows the power structure of a single phase hybrid asymmetric multilevel inverter with the cells in cascade. The magnitude of dc voltage sources increases by factor $2 \mathrm{~s}-$ $\mathrm{n}$. The peak magnitude in the output is given by $(2 \mathrm{~S}-$ $1)^{*} \mathrm{Vdc}$. The output waveform has number of levels equal to $(2 S+1-1)$. For $S=2$ number of levels are seven.

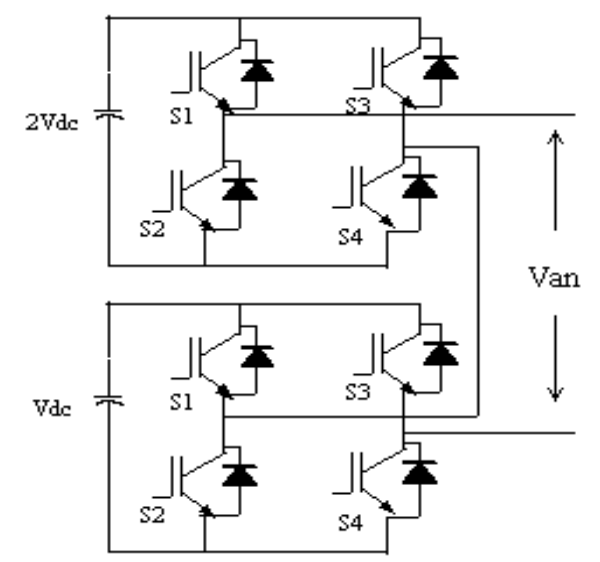

(a)

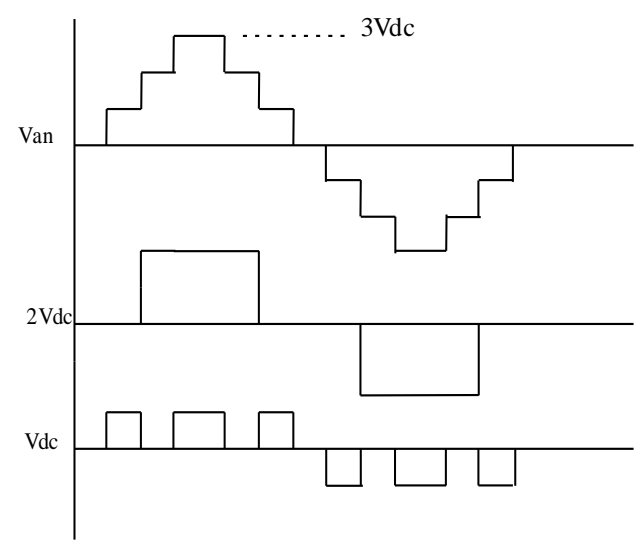

(b)

Fig.8 a Hybrid Asymmetric Inverter with 7 levels b. Output waveforms.

\section{2) Hybrid Multilevel Inverter With $3^{\mathrm{S}-\mathrm{N}} \mathrm{V}_{\mathrm{DC}}$ Factor}

In this $\mathrm{dc}$ sources used are $1 \mathrm{Vdc}, 3 \mathrm{Vdc}, 9 \mathrm{Vdc}$ and number of output levels is equal to $3 \mathrm{~S}$. For $\mathrm{S}=2$ the number of levels obtained is nine and voltage levels are $+-4 \mathrm{Vdc},+-$ $3 \mathrm{Vdc},+-2 \mathrm{Vdc},+-1 \mathrm{Vdc}$ and 0 . The maximum output voltage peak is given by $((3 S-1) / 2)^{*}$ Vdc. Fig.9. shows a hybrid topology and output waveforms. Moreover, to obtain a uniform step multilevel inverter, the dc voltage sources of the H-bridge cells must also respect the following relation [35][36] 


$$
V j \geq 1+2 \sum_{k=1}^{j-1} V k j=2,3 \ldots n
$$

Where it is also considered that the dc voltage sources are arranged in an increasing way that is $\mathrm{V} 1 \leq \mathrm{V} 2 \leq \mathrm{V} 3 \leq \ldots \leq$ $\mathrm{Vn}$. Therefore maximum number of levels of output phase voltage waveform can be given by

$$
m=1+2 \sigma_{n}
$$

where $\sigma_{n}=\sum_{j=1}^{w_{j}} W_{j}$

From the above equation it is possible to verify that asymmetric multilevel inverters can generate a larger number of levels with same number of cells. The advantages over the topology with symmetric DC sources are the for same number of cells, the number of levels is increased and the stage with the higher DC link voltage has lower number of commutation, means lower switching frequency thereby reducing switching losses.

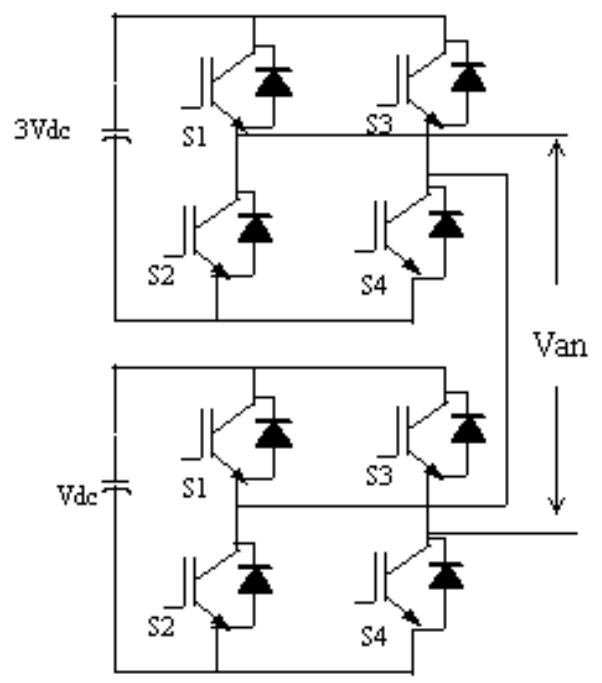

(a)

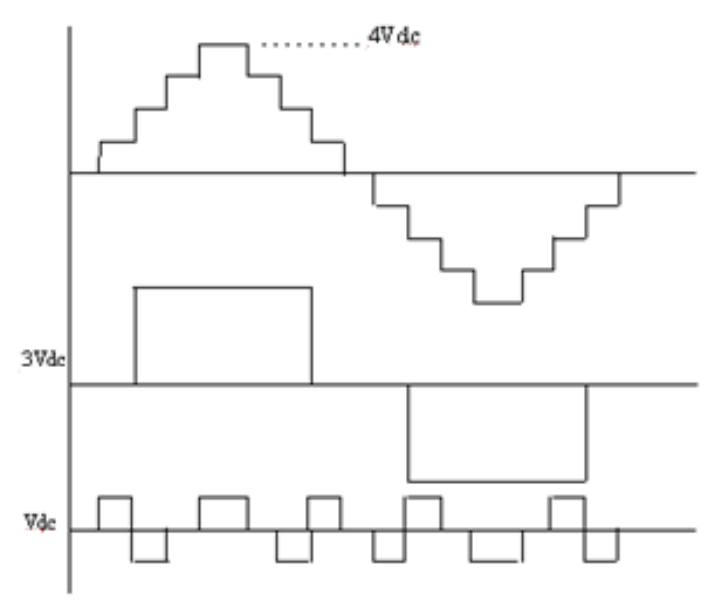

(b)

Fig. 9 a Hybrid asymmetric Inverter with 9 levels. b. Output waveforms

The different topologies of multilevel inverter are discussed. Among this cascade multilevel inverters are most useful for harmonic and reactive power compensation in high voltage system as it solves the size-and-weight problems of conventional transformer-based multipulse inverters and the component-counts problems of multilevel diode-clamped and flying-capacitor inverters. Fig.10 shows the three phase multilevel inverter used for active power filter application. In this Is is the AC source current, IL is nonlinear load current where three phase diode rectifier with $\mathrm{R}-\mathrm{L}$ load is used as nonlinear load, If is the compensated current from APF then

$$
I_{s}=I_{L}+I_{c}
$$

In operation of APF, the harmonic component of load current is derived through harmonic detection circuit and reverses it as the reference compensated current. Then switching signals for multilevel inverter are generated such that AC side output current of APF correctly trace reference current and provides the harmonic current of the load so that source current will be free from harmonics and approaches towards pure sinusoidal[6].

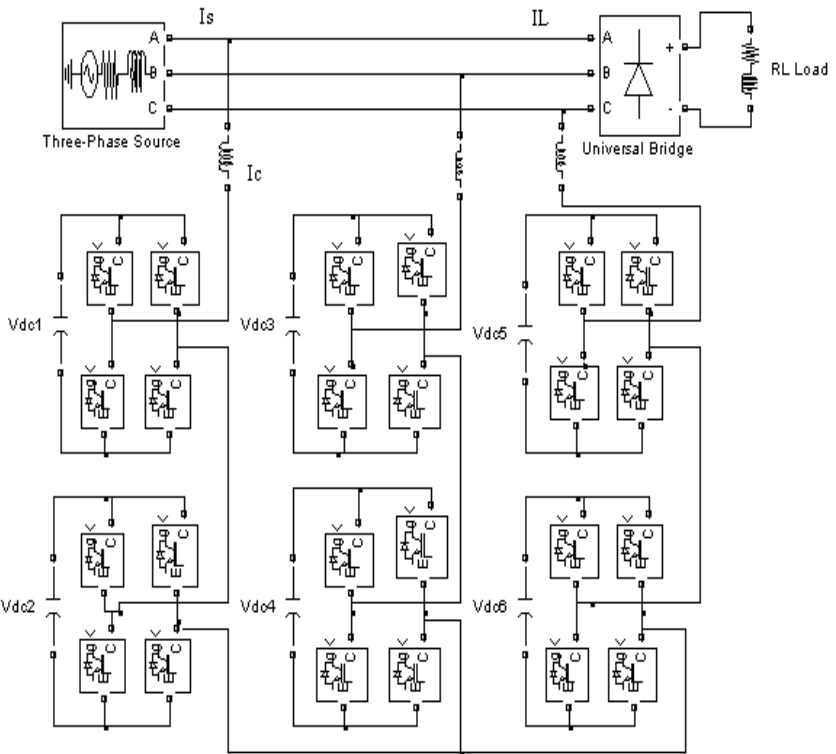

Fig.10. Multilevel Inverter Based APF

In this application there is no need of active power output from the inverter. So separate dc source for each converter bridge is not required. The APF will draw small power from source to compensate the switching losses and capacitor losses in the inverter. DC voltage of each converter should be balanced and to achieve it, the capacitor voltages are sensed and compared with reference and the error is fed to PI controller to generate loss component of APF. This component is added to fundamental load current component which is obtained by average load power. The total current is compared with source current to generate reference currents.

\section{CONTROL STRATEGIES}

The control methodology of APF is key element for its successful performance in mitigating the harmonics and is implemented through three steps.

Step1 Signal Conditioning

Step2 Estimation of compensating signal

Step3 Generation of firing signals for switching devices

\section{A. Signal conditioning}

In order to implement the control algorithm, on line measurement of various voltage and current signals such as ac mains voltage, DC link voltage, load, source and filter 
currents are required. Available advanced sensors have offered great ease of accurate signal conditioning. These signals are also useful to monitor, measure and record various performance indexes, such as total harmonic distortion (THD), power factor, active and reactive power, crest factor etc.

\section{B. Estimation of Compensating Signals}

Estimation of compensating signal is the most important part of the active filter control. It has great impact on compensation objectives, rating of active filter and its transient as well as steady state performance. There are different approaches for extracting current or voltage harmonics from the corresponding distorted current or voltage.

\section{1) Frequency-Domain Approach}

Fourier transform is applied to the captured current or voltage signal. Compensating harmonic components are separated by eliminating the fundamental component and inverse Fourier Transform is applied to derive compensating reference signal in time domain. The main disadvantages of this technique are the time delay for sampling and computation of Fourier coefficients. Most of the frequency domain technique depends on FFT for disturbance extraction and does not give any indication about time and needs at least one cycle to extract any disturbance. This makes it difficult for real time application with dynamically varying load.

\section{2) Time-Domain Approach}

Time domain approach is based on instantaneous derivation of reference signal in the form of either current or voltage signals from distorted signals. There is large number of techniques available in time domain.

\section{a) Instantaneous Reactive power Theory:}

The instantaneous active and reactive power theory has been widely used method for estimation of compensating signals. Akagi et. al. in[37] have presented a new instantaneous reactive power compensator comprising switching devices without energy storage components, based on this theory. This theory is further used for the control of shunt and series filters [38][39]. The 'p-q' theory is based on the $\alpha \beta$ o transformation which transforms three phase voltages and currents into the $\alpha \beta \mathrm{o}$ stationary reference frame. From these transformed quantities, instantaneous real and reactive power of the load is calculated which consists of DC component and an oscillating component. The oscillating component is extracted using high pass filter and taking inverse $\alpha-\beta$ transformation compensating command signals in terms of either currents or voltages are derived[40]-[44].

The three phase voltages and currents are transformed into $\alpha-\beta$ orthogonal coordinates according to the equations (4) and (5) [45]-[46].

$$
\left[\begin{array}{c}
v_{\alpha} \\
v_{\beta}
\end{array}\right]=\sqrt{2 / 3}\left[\begin{array}{ccc}
1 & -1 / 2 & -1 / 2 \\
0 & \sqrt{3} / 2 & -\sqrt{3} / 2
\end{array}\right]\left[\begin{array}{l}
v_{a} \\
v_{b} \\
v_{c}
\end{array}\right]
$$

And

$$
\left[\begin{array}{l}
i_{\alpha} \\
i_{\beta}
\end{array}\right]=\sqrt{2 / 3}\left[\begin{array}{ccc}
1 & -1 / 2 & -1 / 2 \\
0 & \sqrt{3} / 2 & -\sqrt{3} / 2
\end{array}\right]\left[\begin{array}{l}
i_{a} \\
i_{b} \\
i_{c}
\end{array}\right]
$$

The instantaneous active and reactive power in $\alpha-\beta$ coordinates are calculated by following expressions

$$
\begin{aligned}
& p_{(t)}=v_{\alpha} i_{\alpha}+v_{\beta} i_{\beta} \\
& q_{(t)}=-v_{\alpha} i_{\beta}+v_{\beta} i_{\alpha}
\end{aligned}
$$

The fundamental active power component is extracted by using low pass filter. APF loss component obtained by controlling DC capacitor voltages are added to fundamental active power. The compensating currents in $\alpha-\beta$ plane are derived by using equation (7).

$$
\left[\begin{array}{l}
i_{\alpha}^{*} \\
i_{\beta}^{*} *
\end{array}\right]=\frac{1}{v_{\alpha}^{2}+v_{\beta}^{2}}\left[\begin{array}{cc}
v_{\alpha} & v_{\beta} \\
v_{\beta} & -v_{\alpha}
\end{array}\right]\left[\begin{array}{l}
p \\
q
\end{array}\right]
$$

Then three phase currents are obtained by following two phase to three phase transformation

$$
\left[\begin{array}{l}
i_{a} * \\
i_{b} * \\
i_{c} *
\end{array}\right]=\sqrt{\frac{2}{3}}\left[\begin{array}{cc}
0 & 1 \\
-\frac{1}{2} & \frac{\sqrt{3}}{2} \\
-\frac{1}{2} & -\frac{\sqrt{3}}{2}
\end{array}\right]\left[\begin{array}{l}
i_{\alpha}^{*} \\
i_{\beta} *
\end{array}\right]
$$

These currents are compared with source currents and error is processed through PI controller to generate reference currents for APF. The block diagram of the control scheme of shunt active power filter is shown in Fig.11. The advantage of $p-q$ theory is that real and reactive powers associated with fundamental components are dc quantities. These quantities can be extracted with low pass filter. Since the signal to be extracted is dc, $\alpha-\beta$ reference frame is insensitive to any phase shift errors introduced by low pass filter, improving compensation characteristics of the active power filter [47]. The limitation of this theory is the requirement of pure sinusoidal supply voltages which are not true in general. In most industrial power system mains voltages are often unbalanced and distorted. Also the implementation is complex as it requires more hardware.

Several other improved algorithms are proposed for the control of active filters but most of them are very complicated and not easy to implement. Furuhashi et.al [48], presented a study on the theory of instantaneous reactive power, but did not considered the active alternating power and zero sequence power accurately. Watanabe et.al. [49] have explained the physical meaning of real and imaginary powers. It is also presented physical meaning of the zerosequence instantaneous power and analyzed the concept of symmetrical components in unbalanced systems.

A generalized theory of instantaneous reactive power has been proposed for three phase power systems [50]. This theory is valid for sinusoidal or non-sinusoidal, balanced or unbalanced three phase systems, with or without zero sequence currents or voltages. Definitions of the active and reactive power, active and reactive current, power factor etc. are presented and their properties, relationships and physical meanings are also described in detail. 


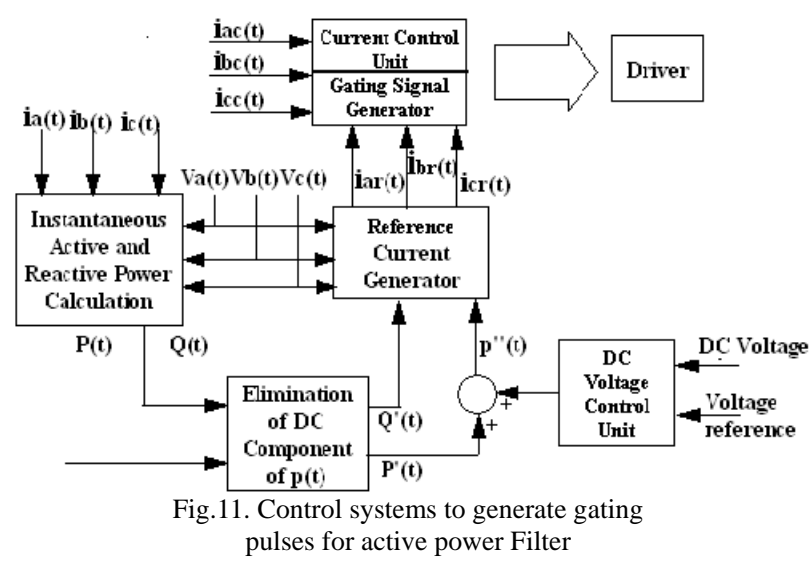

b) Synchronous 'd-q' Reference Frame based Algorithm

This algorithm relies on the Parks transformation where three phase voltage and current signals are transformed to a synchronously rotating frame. The active and reactive components of the system are represented by direct and quadrature component respectively. In this approach, fundamental quantities become d-c quantities [51] which can be separated using notch filters. To implement the synchronous reference frame some kind of synchronizing system (PLL) should be used. The system is very stable as controller handles only dc quantities.

\section{c) Average Power Method}

In [52] [53] the reference peak source current has two components. One is fundamental active power component of load current and computed from average load power (Ps). The second component of source current is to maintain the average capacitor voltage to desired value. This later component of source current is to feed the losses in the converter such as switching loss, ohmic loss and capacitor leakage loss in the steady state and to maintain the stored energy on the dc bus during transient conditions such as sudden fluctuations of load etc. this component of source current is computed using dc bus capacitor value $(\mathrm{Cdc})$, average voltage of $\mathrm{dc}$ bus $(\mathrm{Vdc})$ and a chosen reference voltage of dc bus ( $\left.\mathrm{Vdc}^{*}\right)$. The error voltage is given to P I controller to generate loss component I*smd

The reference value of the current component to the load I*smp is computed using the sensed average load power Pave. The sensed load currents (iLa,iLb,iLc) and bus voltages (va, vb, vc) through PLL are used to derive the instantaneous power $\mathrm{pL}$ as given by

$$
p_{L}=v_{a} * i_{L a}+v_{b} * i_{L b}+v_{c} * i_{L c}
$$

The average power Pave is calculated by averaging instantaneous power over one sixth of time period of supply frequency [8]. The peak current component of load current $I^{*}$ smp is calculated using following relation

$$
P_{\text {ave }}=1.5 * V_{p k} * I^{*} \text { smp }
$$

The reference value of peak current required to provide the losses in APF is I*smd and obtained by comparing the reference voltage and actual capacitor voltages. The actual capacitor voltage is average voltage of capacitors used in each phase. The estimation of I*smd is shown in Fig.5. The total peak reference source current I*sm is computed as sum of these two components. The three phase instantaneous reference source currents $(i * s a, i * s b, i * s c)$ are computed by multiplying peak value I*sm with unit current templates (usa, usb, usc) derived from sensed bus voltages (va, vb, vc). The desired references of the APF currents( $i * c a, i * c b, i * c c)$ are computed by taking the difference between the three phase instantaneous reference source currents $(i * s a, i * s b$, $i^{*} \mathrm{sc}$ ) and actual source currents( isa, isb ,isc) as below

$$
\begin{aligned}
& i^{*} c a=i{ }^{*} s a-i s a \\
& i^{*} c b=i{ }^{*} s b-i s b \\
& i^{*} c c=i{ }^{*} s c-i s c
\end{aligned}
$$

These reference currents are compared with triangular carriers to generate switching signals. The block diagram for reference current generation is shown in Fig.12.

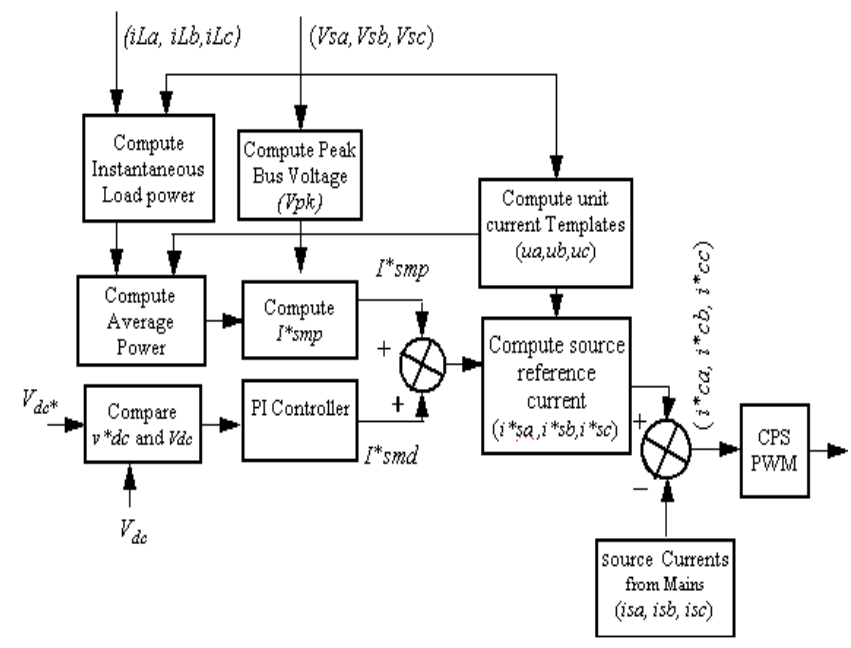

Fig.12. Block diagram for Reference Current Generation

\section{d) Energy Balanced Method}

In [54] the peak reference source current is determined from the viewpoint of energy balance in source, load and APF. In case of distorted supply voltage, the fundamental positive sequence voltage of supply voltage is extracted to synchronize the compensation current reference. In [45] to overcome the limitations of $\mathrm{p}-\mathrm{q}$ theory in active power filter, the synchronizing PLL circuit determines quickly the frequency and phase angle of the fundamental positive sequence component of the measured load currents. The algorithm is based on instantaneous active three phase power expression. The number of equations is reduced and also only load current measurements are required and not supply voltages.

\section{Generation of switching signals.}

The APF switching signals are derived by comparing reference source currents and the sensed actual currents in a current controller. Different approaches such as hysteresis controller, predictive controller and SVM are used.

\section{1) Hysteresis -Band Current Controller:}

In this method the actual current continually tracks the command current within hysteresis band. Preset upper and lower tolerance limits are compared to the extracted error signal. As long as the error is within the tolerance band, no switching action is taken. Switching occurs whenever the error leaves the tolerance band. The hysteresis current control is the fastest method with minimum hardware and 
software. Generally, hysteresis based current controller is used. But in this, switching frequency is not constant and causes more switching losses which limits its use in high frequency and high voltage applications.

\section{2) Carrier Phase Shifted PWM (CPS-PWM)}

Wang Liqiao et.al. [55] have used carrier Phase shifted PWM in shunt active power filter based on five level cascade converter. In the phase shifted multicarrier modulation all triangular carriers have same frequency and the same peak to peak amplitude but there is a phase shift between any two adjacent carrier waves of magnitude given by

$$
\phi_{c r}=360^{\circ} /(m-1)
$$

where $\mathrm{m}$ is the voltage levels of multilevel inverter. Gate signals are generated by comparing the modulating wave with the carrier waves. The carriers Tw1 andTw2, with 900 phase shift are used to generate gating for the upper switches in left legs of power cells $\mathrm{H} 1$ and $\mathrm{H} 2$ respectively in five level cascade converter based active power filter. The inverted signals are used for upper switches in the right legs. The gate signals for all lower switches operate in a complementary manner with respect to their corresponding upper switches.

In this PWM method the equivalent switching frequency of the whole converter is $(\mathrm{m}-1)$ times as the each power device switching frequency. This means CPS-PWM can achieve a high equivalent switching frequency effect at very low real device switching frequency which is most useful in high power applications [56]-[59].

\section{3) Predictive Control}

In [60] a control strategy based on dynamic programming control is presented in which the reference current of the APF for specified future time period is predicted. A. M. Massoud et al.[61] have used the measured supply currents and voltages of common coupling point to predict the reference output voltage of the inverter, required to make the measured current reach its reference at the next sampling instant. Two popular approaches to prediction or forecasting problems are statistical time series modeling method and the use of neural networks. Estimation of reference signal at next sampling value is obtained by rotating the present sampling value through an angle in $\alpha-\beta$ plane using the rotation matrix. The first approach is rather complicated and amount of computation is large. On the other hand ANN offers fast computation speed because of parallel nature and adaptability to changing parameters. In spite of the superior performance the predictive controllers have drawbacks that they require considerable calculations and a good knowledge of system parameters is critical for their implementation [62].

\section{4) Space Vector Modulation}

The weakness of hysteresis controller can be overcome by conjunction of the space vector modulation technique to the controller. SVM was first introduced by German researcher in the mid of 1980s. This technique showed several advantages over PWM technique. SVM technique can maximize the output voltage and also reduce the switching number at the same carrier frequency of the
PWM method. It gives very low value of output voltage THD. The space vector modulation technique is a fixed frequency approach [63]-[67]

M.I. Marei et. al [68] have presented SVM based hysteresis current controller which combines advantages of both SVM and HCC. The proposed current control block is composed of SVM scheme combined with the HCC switching Technique. The harmonic reference currents acquired from the load current are compared with actual harmonic currents generated by the APF. If there is any discrepancy, then the current error signal has to be fed to the SVM based HCC control block in order to modify switching signal. In the recent literature over modulation for multilevel inverters has been reported. In [69] McGrath explains the behavior of the multilevel carrier based PWM methods for diode clamped, cascade and flying capacitors topologies in over modulation region. In Mondal [70] performs SVPWM based over modulation on a three level NPC inverter. The on time calculation equations differ for every triangular section at any modulation index. Due to increased computational complexity, it is cumbersome to extend this scheme to n-level inverter $(n>3)$. Gupta et.al. [71] have proposed a general SVPWM algorithm for multilevel inverters based on standard two-level SVPWM. A simple method of calculating on-times, based on on-time calculation for two levels SVPWM is used for $\mathrm{n}$ level inverter and complexity of computation is reduced.

The implementation of MLI based active power filter in high voltage system is validated by simulation results. Fig.13 shows waveforms of supply voltage, nonlinear load current, filter current and source current after compensation. The supply line voltage is $11000 \mathrm{Vrms}$ and nonlinear load is three phase uncontrolled bridge converter with R-L load on dc side. Fig. 14 shows the frequency spectrum of load current and source current after compensation. The load current THD is $24.56 \%$. and supply current THD reduces to $1.95 \%$ after compensation which is within IEEE standard recommendations. Thus it proves that MLI based APF compensates harmonics successfully in high voltage systems without use of high rating coupling transformer.
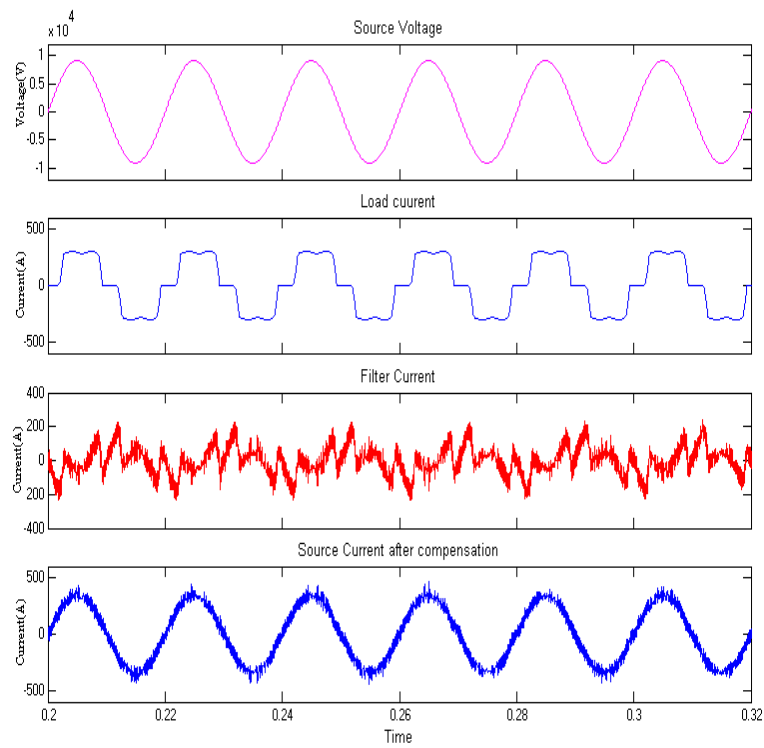

Fig.13. Waveforms of ideal mains voltage, load current, filter current and source current after compensation in steady state condition 


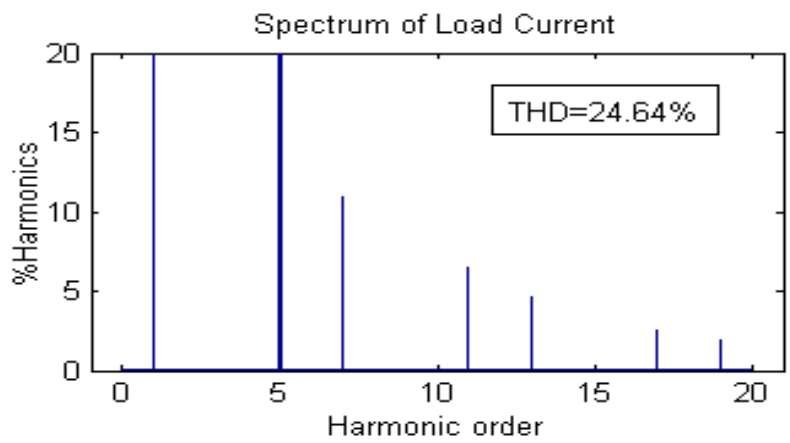

(a) Spectrum of the nonlinear load current IL

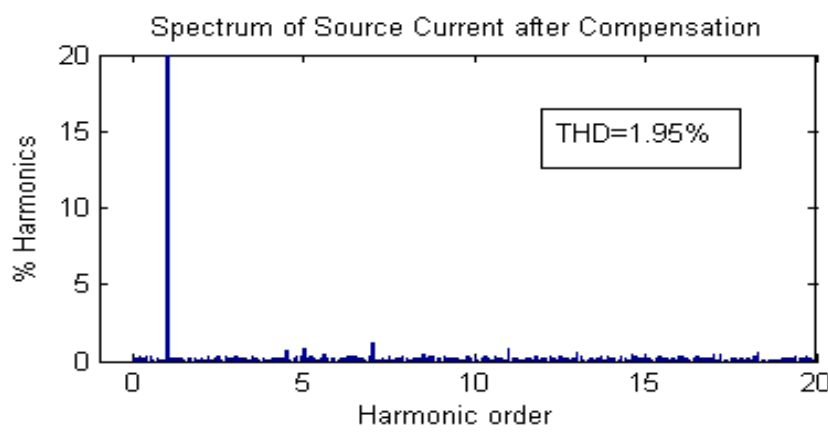

(b) Spectrum of source current Is

Fig.14. Frequency spectrum of load current and source current with ideal mains voltage

\section{CONCLUSION}

An extensive review of MLI based APF's has been presented to provide a clear perspective on various aspects of the APF to researchers and engineers in this field In high and medium voltage system, multilevel inverter based active power filter is an attractive alternative for harmonic compensation as it does not require coupling transformer. Cascaded inverter is a most suitable and competitive configuration among all the available topologies of multilevel inverter.

Generation of reference supply current is important as compensation performance depends on it. There are different techniques to generate reference signal in Frequency domain and Time domain. There exist different modulation techniques for multilevel inverters such as hysteresis controller, predictive controller and SVM. Space vector Modulation technique is considered as one of suitable methods as it gives low switching losses and good capacitor voltage balancing.

\section{REFERENCES}

[1] Hirofumi Akagi, "Trends in active power line Conditioners ", IEEE Trans. on Power Electron. Vol.9, no.3 May 1994,pp.263-268.

[2] Bhim singh, Kamal Al-Haddad, A. Chandra: "A review of Active filters for power quality improvement", IEEE trans. on Industrial electronics, vol.46,no.5 pp. 960-971, Oct. 1999

[3] A.Nabae, I. Takahashi ,H Akagi, "A new neutral -point clamped PWM inverter”, IEEE Trans. Ind. Applications vol.IA - 17, pp 518523 Sept 1981

[4] T. Tanaka ,Eiji ahiraki, Y. Omura, M. Yamamoto, “A Novel Real Time detection Method of Active and Reactive Currents for single phase Active Power Filters", in proc of IEEE conf. 2007 pp.29332938.

[5] R.H. Baker and L.H. Bannister, 'Electric power converter', U.S Patent 3867643, Feb 1975.

[6] P.W. Hammond, 'Medium voltage PWM drive and method', U.S Patent 5625545 Apr.1997.

[7] F.Z. Peng And J.S Lai, 'Multilevel cascade voltage source inverter with separate DC sources', U.S Patent 5642275 June 1997.

[8] N.S. Choe, J.G. Cheo, "A General circuit topology of multilevel inverter”, IEEE-PESC 91 Conference Record,pp.96-103,1991.

[9] Z. Du, L.M. Tolbert, J N. Chiasson, "Active harmonic elimination for multilevel converters", IEEE Trans. on Power Electon., vol.21, no.2, pp.459-469, March 2006.

[10] J. Rodriguez. Sheng lai , F.Z.Peng, “ Multilevel inverters: A survey of topologies controls, and Applications", IEEE Trans. on Ind. Electronics Vol.49, no 4 Aug 2002 pp. 724-738

[11] J.S Lai and F.Z. Peng, "Multilevel Converters-A new breed of power converters", IEEE/PESC Ann. Mtg Vol.2 pp.1121-1126 June 1997.

[12] T.A. Meynardand H.Foch "Imbricated cells multilevel voltage source inverters for high voltage Applications", European power electronics Journal, vol.3 pp.99-106, June 1993

[13] L.M. Tolbert, F. Z. Peng, "Multilevel converters for large electric drives", IEEE Trans. on Industry applications, Vol.35, no.1, pp-36-44, 1999.

[14] R. W. Menzies, P. steamer and J.K. Steinke, "Five level GTO inverters for large induction motor Drives", IEEE/IAS Annual Meeting pp.595-601,1991

[15] C.Hochgraf, R. Lasseter, "Comparison of multilevel inverters for static var compensation”, Wisconsin EMPE Con. Sept.1994, pp.921928

[16] B.S Suh, G. Sinha,M. Manjrekar, "Multilevel power conversion-An overview of topologies and modulation strategies", in proc. of International conference on Optimization of Electrical and Electronic Equipments, May 1998, Vol.2, pp.AD11-AD-24

[17] Dixon J. Moran L. "Multilevel inverter, based on multi-stage connection of three level converters scaled in power of three", in proc. of 28th annual conference of the Industrial Electron. Society, IEEE 2002, vol.2, Nov. 2002, pp.886-891.

[18] V. Aburto, M. Schneider, L. Moran, "An active power filter implemented with a three level NPC voltage source inverter", 28th annual IEEE Power Electronics specialists conference,vol.2, pp 22752279, oct.2002.

[19] X.Wang, Yan Deng, "Active power filter based on four -leg hybrid clamped Technique", Institute of Power Electronics, 2007, pp.458463.

[20] Sun Hui, Zou Ji-yan:, "A novel active power filter using multilevel converter with self voltage balancing', IEEE 2002 pp, 2275- 2279

[21] Yehia Tadros, Gunter Junge, "Design aspects of high power inverters with GTO”, EPE'91 Conf. Proc. Vol.2, pp.083-88, 1991

[22] Jing Haung, K.Corzine, "Extended operation of flying capacitor multilevel inverters", IEEE Trans. on power Electronics, vol.21, no.1, pp.140-147, Jan.2006.

[23] B.M. song, J.S Lai, "Soft switching high voltage active power filter with flying capacitors for urban Maglev system applications", IEEE 36th annual Meeting conf. of the Industry applications vol.3 Oct 2001, pp-1461-1468

[24] Y. Liang, C.O. Nwankpa, "A power line conditioner based on flyingcapacitor multilevel voltage-source converter with phase-shift SPWM", IEEE Transactions on Industry applications,vol.36,no.4, pp.965-971July 2000

[25] F.Z.Peng, J. W. Mckeever, D.J. Adams, "Cascade multilevel inverters for utility applications", IECON97, 23rd International Conference on Industrial Electronics, Control and Instrumentation, vol.2, pp437-442, 1997

[26] F.Z Peng, J.S Lai, "Dynamic performance and control of a static var generator using cascade multilevel inverters", IEEE Trans. On Industry applications, vol.33, no 3, pp748-754, 1997

[27] F. Z. Peng, Mckeever J W, "A Power Line Conditioner using cascade multilevel inverter for distribution systems", IEEE Transactions on Industry Application vol.43, no. 6 ,Nov 1998, pp.1293-1298.

[28] Fang Zhengpeng, Jih Sheng Lai, "A multilevel voltage source inverter with separate DC source for static var generation", IEEE Trans. On Industry Applications, Vol.32 No.5, pp1130-1137, 1996

[29] K.A. Corzine, M.W. Wielebski, "Control of cascaded multilevel inverters", IEEE Trans. on power Electronics, vol.19, no.3 May 2004, pp.732-738

[30] G. Wang, Y. li,X. You, "A novel control algorithm for cascade shunt active power filters", IEEE 35th annual Power Electronics specialists' conference vol. 1, pp 136-141, Sept. 2004. 
[31] M.D. Manjrekar, P.k. Steamer and T.A. Lipo, "Hybrid multilevel power conversion system: a competitive solution for high power applications", IEEE Trans. on Industry applications vol.36,pp 834841 ,May 2000

[32] H. Miranda, V. Cardenas, "Hybrid control scheme for single phase shunt active power filter based on multilevel cascaded Inverter", in proc. of power Electronics Specialists conference, June 2007, pp.1176-1181

[33] H. Miranda V. Cardens J Perez, "A Hybrid multilevel inverter for shunt active filter using space vector control", in 35th Annual IEEE power electronics Specialists Conference 2004, pp 3541-3546.

[34] Miguel Lopez L. Mortin J. Espinoza, "Performance analysis of a hybrid Symmetric multilevel inverter for high voltage active power filter applications", in Proc. of IEEE Industrial Electronics Society Annual Conference 2003, pp. 1050-1055.

[35] J.S. Manguelle, A. Rufer,M. Veenstra, "A generalized design principle of a uniform step asymmetrical multilevel converter for high power conversion", in proc. of European Conference on Power Electronics and Applications, Aug 2001

[36] Y. Fukuta , G. Venkataramanan, "DC bus ripple minimization in cascaded H-bridge multilevel converters under staircase modulation", IEEE, IAS conf.2002, vol.3, pp.1988-1993

[37] Akagi H, Nabae A, "Instantaneous reactive power Compensators comprising switching devices without energy storage components', IEEE Trans. on Industry Application, vol.IA 20.No 3 May/June 1984 pp-625-630

[38] Akagi H, Nabae A, "Control strategy of active power filters using multiple voltage source PWM Converters", IEEE Trans. on Industry applications, Vol IA 22 No 3 May/June 1986 pp.460- 465.

[39] Bhim Singh and K.A Haddad, "A new control approach to three phase active filter for harmonic and reactive power compensation", IEEE Trans. on Power System, vol.13, No.1, Feb 1998, pp.133-138.

[40] C.W Chang, "A new method for determining reference compensating currents of the three phase shunt active power filter", IEEE power engineering review, pp 63-65, March 2001.

[41] A. Chandra, B. Singh , K. Al-Haddad, "An improved control algorithm of shunt active filter for voltage regulation, harmonic elimination ,power factor correction and balancing of non -linear Loads", IEEE trans. Power Electron.,vol.15 no.3 pp-495-506, May 2000.

[42] Ali Ajami, S.H Hosseini, "Implementation of a novel control strategy for shunt active filter", ECI Transactions on Electrical Eng. Vol-4 No1 Feb 2006

[43] G. Zhou, Bin Wu d. Xu, "Direct power control of multilevel inverter based active Power filter", IEEE International conf. on Industrial Technology (ICIT)- 2004, PP. 498-503

[44] W. M. Grady, M.J. Samoty and A.H. Noyola, "Minimizing network harmonic voltage distortion with an active power line conditioner",IEEE Trans. Power Delivery , vol.6,pp.16901697.oct1991.

[45] Akagi H. Tsukamoto Y, Nabae A, "Analysis of an active power filter using quad series voltage source PWM converters", IEEE Trans. on Industry applications vol. 26 no 1, Jan/Feb 1990 pp93-98.

[46] D.Iannuzzi, L.Piegari and P.Tricoli, "An active filter used for harmonic compensation and power factor correction: a control Technique", IEEE Power Electronics Specialists Conference, June 2008, pp 4631-4635.

[47] J. Allmeling, "A control structure for fast harmonics compensation in active filters", IEEE Trans. on Power electronics, vol.19, no 2, march 2004.

[48] T. Furuhashi,S.,S. Okuma and Y. Uchikawa, "A study on the theory of instantaneous reactive power", IEEE Trans. on Industrial electron. Vol.37, p.86-90, 1990

[49] Watanabe E.H, Stephan R.M. and Aredes M. "New concepts of instantaneous active and reactive powers in electric systems with generic loads", IEEE Trans. on power delivery, vol.8,no.2 April 1993 , pp.697-703.

[50] F.Z Peng J.S Lai, "Generalized instantaneous reactive power theory for three- phase power systems", IEEE Trans. on Instrumentation and Measurement, vol.45 No1 Feb 1996, pp. 293-297

[51] S. Bhattacharya, D.M. divan and b. Banerjee, "Synchronous frame harmonics isolator using active filters", in proc. of European power Electronics conf. EPE 1991, pp. 2531-2540

[52] Mauricio Aredes , F.C Monteiro, "A Control Strategy for shunt Active Filter" in proc. IEEE Harmonics and Quality of Power Conf. Vol 2 pp.472-477 Oct 2002

[53] Che Yanbo Zhou Fudan, "Shunt active power filter-SIMULINK simulation and DSP-based hardware realization", 2nd International Conf .on Power Electronics Systems and Applications, pp120-125, 2006.
[54] Gong Maozhong, Liu Hankui, "A Novel method of calculating current reference for shunt active power filters without Hardware Synchronization", in proc.of IEEE power conversion conference, 2002, vol.2, pp:795-799.

[55] W. Liqiao, L Ping Z. Zhongchao, "Study on shunt active power filter based on cascade multilevel converters", in 35th Annual IEEE power electronics Specialists Conference 2004, pp.3512-3516

[56] B.P. McGrant and D.G.Holmes, "Multicarrier PWM strategies for multilevel inverters", IEEE Trans. on Industrial Electron. Vol.49 Aug.2002, pp. 858-867

[57] [A.M. Massoud, S,J. Finney,B.W Williams, "Control techniques for multilevel voltage source inverter", IEEE 34th Power Electron. Specialists Conference 2003, vol.1, pp.171-176.

[58] D.G Holmes and B.P McGrath, "Opportunities for harmonic cancellation with carrier-based PWM for two-level and multilevel Cascaded Inverters", IEEE Trans. on Industry Applications, vol.37, No 2 pp 574-582, 2001.

[59] M.Fracchia, T. Ghiara, M.Marchesoni, "Optimized modulation techniques for generalized N-level converter", in proc IEEE power Electronics specialist conference, 1992, pp. 1205-1213

[60] H. Ghoudjehbaklou,A Kargar, "A new predictive control strategy for active power filters", in Proc. of IEEE International Conference on Electronics circuits and systems, 1999, vol.1 pp171-176.

[61] A.M Massoud S.J.Finney, "Seven Level Shunt active power Filter", 11th International conference on Harmonics and Quality of Power Proc. 2004, pp136-140.

[62] Gautam Sinha,Thomas Lipo, "A new modulation Strategy for improved DC bus utilization in Hard and soft switched multilevel inverters", IEEE-IECON'97 conference proceeding vol.1 pp.670675,1997

[63] Kliang Zhou and Danwei Wang, "Relationship between Space vector modulation and three phase carrier-based PWM: A comprehensive analysis", IEEE Transactions on Industrial Electronics, Vol.49, No 1, Feb 2002.

[64] J.H.seo, C.H. Choi, and D.S. Hyun, "A new simplified space-vector PWM method for three level inverters", IEEE Trans. Power Electron., vol.16, no.4pp 545-550,Jul. 2001.

[65] B.P. McGrant and D.G.Holmes, "Sinusoidal PWM of multilevel inverters in the over modulation region", in proc.IEEE 33rd Annu. Power electron.Spec. conf. Jun.2002. vol.2,pp485-490.

[66] F.Bauer,h.D Heining, "Quick response space vector control for a high power three level inverter drive System", EPE,89, conference proceedings,pp-417-421,1989

[67] Jose R. Espinoza, Geza Joos and Hua Jin, "Modeling and Implementation of Space Vector PWM Technique in active filter applications", in Proc of IEEE workshop on computers in Power Eectronics, Aug 1996, pp 142-146.

[68] M.I. Marei, E.F EI-Saadany, M.M.A. Salama, "A new contribution into performance of active power filter utilizing SVM based HCC technique", IEEE Power Engineering Society Summer Meeting, July 2002, Vol. 2, pp 1022-1026.

[69] B.P. Mcgrath,D.G. Homles, T.A. Lipo, "Optimized space vector switching sequences for multilevel Inverters", IEEE Trans. Power Electron.Vol.no 18, no.6, pp 1293-1301, Nov.2003.

[70] S.K. Mondal, B.K. Bose, V. Oleschuk and J.O.P Pinto, "Space vector pulse width modulation of three level inverter extending operation into overmodulation region", IEEE trans. Power electron. Vol.18, no.2, pp. 604-611, March 2003

[71] A.K. Gupta, A.M. Khambadkone, K.M. Tan, "A two -level inverter based SVPWM algorithm for a multilevel inverter", in Proc. Annu. Conf. IEEE Ind.Electron. Soc.(IECON), Nov.2004, Vol.2,pp18231828.

Madhukar Waware completed B.E in Electrical Engineering in 1999 and M.E in Control System in 2003 from Walchand College of Engineering (WCE) Sangli, Maharashtra, India. He is faculty member in EED in WCE Sangli and presently pursuing Ph.D program in Electrical Engineering Department, Indian Institute of Technology Roorkee, India.

Pramod Agarwal obtained B.E, M.E and Ph.D degree in Electrical Engineering from University of Roorkee, now Indian Institute of Technology Roorkee (IITR), India. Currently he is a professor in the department of Electrical Engineering, IITR. His fields of interest include Electrical Machines, Power Electronics, Power Quality, Microprocessors and microprocessor-controlled drives, multilevel converters and applications of dSPACE for the control of Converters. He is a member of IEEE. 